\title{
Carbamazepine-Induced Tics
}

\author{
Patricia L. Robertson, Elizabeth A. Garofalo, Faye S. Silverstein, and \\ Mary Ann Komarynski \\ Departments of Pediatrics and Neurology, The University of Michigan, Ann Arbor, Michigan, U.S.A.
}

\begin{abstract}
Summary: A variety of movement disorders are known to occur in association with carbamazepine (CBZ) therapy in adults and children, but development of tics has been described infrequently and only in patients with underlying Tourette's syndrome or other movement disorders. We report 3 children with epilepsy who developed facial motor tics after initiation of CBZ for complex partial seizures. All 3 had documented CBZ blood levels in the therapeutic range at the time, and none had other symptoms or signs of clinical intoxication. Neurologic examinations were normal in 2 and showed developmental de-
\end{abstract}

lay of expressive language in the third. Brain imaging was normal in all. After development of the tics in 2, CBZ was continued at the same or higher dose, and the tics abated and then ceased spontaneously $\leqslant 6$ months. In the third child, the tics ceased after CBZ discontinuation. These cases demonstrate that $\mathrm{CBZ}$ can induce simple motor tics in children. These idiosyncratic reactions may be transient and do not always necessitate drug discontinuation. Key Words: Anticonvulsants-Carbamazepine-Drug toxicity-Children-Tic-Movement disorder.
A variety of drug-induced movement disorders have been described in association with antiepileptic drug (AED) therapy, most often with phenytoin (PHT), (Chadwick et al., 1976). Carbamazepine (CBZ) has been implicated as a possible or probable causative factor of various involuntary movements in 26 patients, half of whom were children (Berchou and Rodin, 1979; Crosley and Swender, 1979; Lehrman and Bauman, 1981; Bradbury et al., 1982; Neglia et al., 1984; Weaver et al., 1988; Kurlan et al., 1989; Schwartzmann and Leppik, 1990). The dyskinesias in some patients appeared to represent toxic side effects of high CBZ concentrations, whereas in others the involuntary movements appeared to be idiosyncratic reactions, occurring in patients with therapeutic blood levels. Most previously described CBZ-associated involuntary movements in children were generalized dyskinesias associated with dystonic or choreoathetotic movements in axial or extremity musculature. Development of motor tics in association with CBZ therapy is uncommon and has been reported in only 4 children; in all, CBZ appeared to have precipitated or exacerbated an underlying Tourette's syndrome (Neglia et al., 1984;

\footnotetext{
Received May 1992; revision accepted August 1992.

Address correspondence and reprint requests to Dr. P. L. Robertson at University of Michigan Medical Center, Division of Pediatric Neurology, R 6060 Kresge II, Box 0570, 171 Zina Pitcher Place, Ann Arbor, MI 48109-0570, U.S.A.
}

Kurlan et al., 1989). We report 3 children with no previous history of involuntary movements who developed facial motor tics soon after CBZ initiation.

\section{CASE REPORTS}

\section{Case 1}

A 5-year-boy with a history of developmental language delay and episodes of staring and unresponsiveness had an unremarkable birth and past medical history. Developmentally, fine and gross motor skills were normal. He was able to say single words by age 1 year, but expressive language progressed at a slower than normal rate thereafter. There was no family history of mental retardation, language disability, seizure, or tic disorder. Computed tomography (CT) brain scan was normal. EEG showed frequent left frontocentral spike and slow waves, and the staring episodes were presumptively diagnosed as complex partial seizures. Therapy with CBZ was started at a dosage of $10 \mathrm{mg} / \mathrm{kg} / \mathrm{day}$. Within 2 weeks after initiation of CBZ, facial movements began, consisting of alternately wide opening and then tight closing of his eyes, along with frequent repetitive blinking and jaw clenching. These movements had never been observed before CBZ initiation. Although his family was concerned about the movements, he did not appear to be distressed by them. CBZ blood level at that time was $4.1 \mu \mathrm{g} /$ 
$\mathrm{ml}$, and an EEG showed no correlation of the movements with any epileptiform activity. The involuntary movements were diagnosed as motor tics. Because CBZ had abolished the staring spells and the child's speech had become significantly more fluent, no CBZ dosage changes were made. Blinking and other facial movements decreased in the next 2 months, although CBZ level remained unchanged. After 4 months of CBZ, the question of behavioral side effects was raised, and $\mathrm{CBZ}$ dosage was decreased by $25 \%$. The tics disappeared completely after another 2 more months, at which time the CBZ level was $3.6 \mu \mathrm{g} / \mathrm{ml}$. The CBZ dosage was then restored to the original $10-\mathrm{mg} / \mathrm{kg} /$ day dosage with no recurrence of tics during 6 months of follow-up while receiving $\mathrm{CBZ}$.

\section{Case 2}

A 17-year-old boy had a history of complex partial seizures (CPS) that began at age 2 with viral encephalitis. Seizures were controlled with phenobarbital (PB) and PHT until age 12. AEDs were discontinued until age 15 , when he again began to have seizures refractory initially to $\mathrm{PB}$ and acetazolamide and then to valproate (VPA) and PHT. EEG showed seizure origin in left frontal regions. Past medical history included well-controlled asthma. Developmental history was normal, and he had been an A student in school until grades fell with seizure recurrence. There was no family history of movement or tic disorder. Brain magnetic resonance imaging (MRI) showed no abnormalities. PHT was discontinued, and VPA was changed to CBZ $5 \mathrm{mg} / \mathrm{kg} /$ day. Repetitive eye blinking began 11 days after CBZ initiation. CBZ blood level was 7.2 $\mu \mathrm{g} / \mathrm{ml}$, and VPA blood level was $36 \mu \mathrm{g} / \mathrm{ml}$. There were no other signs of clinical toxicity. Movements did not correlate with any abnormal EEG activity and were diagnosed as facial tics. He had experienced no previous involuntary movements. VPA was discontinued after 9 days with persistence of the blinking. CBZ dosage was increased to $6 \mathrm{mg} / \mathrm{kg} /$ day. Tics began to abate and disappeared $\sim 2$ months after CBZ initiation when the blood level was $7.6 \mu \mathrm{g} / \mathrm{ml}$, but recurred after a further increase in dosage to $8 \mathrm{mg} / \mathrm{kg} / \mathrm{day}$, when the level was 8.4 $\mu \mathrm{g} / \mathrm{ml}$. The tics again resolved after another month and did not recur when the dosage was subsequently increased to $19 \mathrm{mg} / \mathrm{kg} / \mathrm{day}$ and CBZ levels were between 13 and $19 \mu \mathrm{g} / \mathrm{ml}$. No tics were observed for the next 6 months while he continued CBZ.

\section{Case 3}

A 9-year-old boy had a history of several different types of occasional paroxysmal episodes since early infancy, including one with arm jerking and several with sudden loss of postural tone and alteration of consciousness. There was also a 2-year history of throbbing bifrontal headaches that had more recently become associated with visual image distortion and déjà vu phenomena. Past medical history was unremarkable. Developmental milestones had been normal, and he was an honor student in school. Family history was unknown because he was adopted. A diagnosis of migraine headache was considered, but an EEG showed left frontotemporal spikes and polyspikes consistent with the interictal expression of a complex partial seizure disorder. CBZ was initiated at a dosage of $5 \mathrm{mg} / \mathrm{kg}$. Brain MRI showed no abnormalities. Headaches improved initially, but 6 weeks after CBZ initiation repetitive facial movements with mouth opening and tongue curling began. These had never been observed before CBZ. Movements were diagnosed as facial motor tics. CBZ blood level was $3.2 \mu \mathrm{g} / \mathrm{ml}$, and CBZ dosage was not altered. The tics gradually lessened, but because the headaches and visual symptoms became worse, the CBZ dosage was increased to $7.5 \mathrm{mg} / \mathrm{kg} /$ day 4 months after CBZ initiation. Tics became more prominent during the next 2 months. CBZ blood level was only $1.5 \mu \mathrm{g} / \mathrm{ml}$, but several doses had been missed on the day before the blood level was obtained. Because the headaches persisted, primidone (PRM) was initiated, and CBZ tapered and discontinued; subsequently, the tics ceased completely.

\section{DISCUSSION}

Three children developed facial motor tics manifest as repetitive blinking, jaw opening or clenching, and tongue movements $2-6$ weeks after initiation of CBZ therapy. Two received no other drugs. The third (case 2), in whom VPA was being discontinued, received VPA for 9 days after tic onset; the tics then continued for several months. The temporal association of CBZ initiation with tic onset, along with the absence of other likely etiologic factors, suggests that CBZ was the most likely cause.

Tics have been reported in association with $\mathrm{CBZ}$ therapy in only 4 other pediatric patients, 3 of whom had already manifested motor tics that worsened after CBZ initiation (Neglia et al., 1984; Kurlan et al., 1989). Two adults, one with Huntington's disease and the other with Alzheimer's disease, also developed tics superimposed on other types of involuntary movements after introduction of CBZ (Kurlan et al., 1989). In the 4 reported children, the CBZ-induced tics persisted even after CBZ discontinuation, were multifocal, included phonic tics, 
and in 3 required haloperidol for control, suggesting that these children had Tourette's syndrome that was unmasked or exacerbated by the CBZ, as occurs with stimulant medications such as amphetamine (Lowe et al., 1982).

CBZ blood levels of our patients, as of those previously reported with CBZ-associated tics, were in the therapeutic range, suggesting the reaction is idiosyncratic rather than a toxic effect of excessively high CBZ concentrations. Unlike the previous cases, however, our children did not exhibit tics before initiation of CBZ therapy and did not progress to Tourette's syndrome. Moreover, in cases 1 and 2, tic manifestations were transient. Even though CBZ was continued at the same or higher dosage, the tics abated and finally ceased within several months. In case 3, the tics resolved after CBZ discontinuation.

$\mathrm{CBZ}$ has also been reported as a probable cause of other involuntary movements in both adults and children (Berchou and Rodin, 1979; Crosley and Swender, 1979; Lehrman and Bauman, 1981; Bradbury et al., 1982; Critchley and Phillips, 1988; Weaver et al., 1988; Schwartzmann and Leppik, 1990). Eight children were described with generalized dyskinesias; 7 of these had movements that involved axial and/or extremity muscles in dystonic, choreoathetotic, or even ballistic patterns (Crosley and Swender, 1979; Lehrman and Bauman, 1981; Bradbury et al., 1982; Critchley and Phillips, 1988; Weaver et al., 1988), and 1 child developed shivering movements with rigidity and hypokinesia (Critchley and Phillips, 1988). In 4 of the 8 children, CBZ levels were clearly above therapeutic range $(>20 \mu \mathrm{g} / \mathrm{ml})$ and the CBZ had been ingested either accidently or deliberately as an overdose in 3; all 4 also had alterations in level of consciousness. (Lehrman and Bauman, 1981; Bradbury et al., 1982; Weaver et al., 1988). In contrast, the remaining 4 children with generalized dyskinesias (Crosley and Swender, 1979; Critchley and Phillips, 1988), and 1 other child who developed forced upward eye deviation in oculogyric crisis (Berchou and Rodin, 1979), had CBZ levels that either were in the therapeutic range or were not measured. Overdose was not suspected, and no other clinical sign of intoxication accompanied the movements, suggesting that, like the tics we observed, they were idiosyncratic rather than toxic CBZ reactions.

Some of the reported patients who developed abnormal movements during CBZ treatment had significant underlying brain damage and neurologic impairment, and disruption of the integrity of the basal ganglia has been suggested to be a predisposing factor for CBZ-induced movement disorders (Crosley and Swender, 1979). The possibility of some subtle underlying neurologic abnormalities cannot be ruled out in our patients, particularly in case 1 who did have neurodevelopmental abnormalities of speech. Yet these case histories demonstrate that tics can occur when brain imaging shows no structural abnormalities and, in cases 2 and 3, when neurologic examination shows no abnormality.

CBZ at therapeutic levels can induce tics in children who have no underlying movement disorder or major neurologic deficit. The relatively mild and transient nature of CBZ-induced involuntary movements, even when CBZ is continued, suggests that if clinically warranted, it may be feasible to continue CBZ treatment.

\section{REFERENCES}

Berchou RC, Rodin EA. Carbamazepine-induced oculogyric crisis [Letter]. Arch Neurol 1979;36:522-3.

Bradbury AJ, Bentick B, Todd PJ. Dystonia associated with carbamazepine toxicity. Postgrad Med J 1982;58:525-6.

Chadwick D, Reynolds EH, Marsden CD. Anticonvulsantinduced dyskinesias: a comparison with dyskinesias induced by neuroleptics. J Neurol Neurosurg Psychiatry 1976;39: $1210-8$.

Critchley EM, Phillips M. Unusual idiosyncratic reactions to carbamazepine. J Neurol Neurosurg Psychiatry 1988;51: 1238.

Crosley CJ, Swender PT. Dystonia associated with carbamazepine administration: experience in brain-damaged children. Pediatrics 1979;63:612-5.

Klawans H, Falk DK, Nausieda PA, et al. Gillles de la Tourette syndrome after long-term chlorpromazine therapy. Neurology $1978 ; 28: 1064-8$.

Kurlan R, Kersun J, Behr J, et al. Carbamazepine-induced tics. Clin Neuropharmacol 1989;12:298-302.

Lehrman SH, Bauman ML. Carbamazepine overdose. Am J Dis Child 1981;135:768-9.

Lowe T, Cohen DJ, Detior J, et al. Stimulant medications precipitate Tourette's syndrome. JAMA 1982;247:1168-9.

Neglia JP, Glazen DG, Zion TE. Tics and vocalizations in children treated with carbamazepine. Pediatrics 1984;73:841-4.

Schwartzmann MJ, Leppik IE. Carbamazepine-induced dyskinesia and ophthalmoplegia. Cleve Clin J Med 1990;57:367-72.

Weaver DF, Camfield P, Fraser A. Massive carbamazepine overdose: clinical and pharmacologic observations in five episodes. Neurology 1988;38:755-9.

\section{RÉSUMÉ}

Différents types de mouvements anormaux peuvent être liés à la prescription de carbamazépine (CBZ) chez l'adulte et chez l'enfant, mais le développement de tics n'a été décrit que rarement, seulement chez les patients présentant une maladie de Gilles de la Tourette sous-jacente ou d'autres mouvements anormaux. Les auteurs présentent 3 observations d'enfants épileptiques qui ont développé des tics moteurs faciaux après mise en route de CBZ en traitement de crises partielles complexes. Chez les 3 patients, les taux sanguins de CBZ étaient dans les zones thérapeutiques pendant cette période, et aucun n'avait d'autres symptômes ou signes d'intoxication clinique. L'examen neurologique était normal chez 2 patients, le troisième présentant un retard d'expression du langage. La neuroradiologie cérébrale était normale chez les 3 patients. Après l'installation des tics, le traitement par CBZ a été poursuivi chez 2 patients à la même dose ou à une dose supérieure, et les tics ont diminué et ont 
disparu spontanément en moins de 6 mois. Chez le 3ème enfant, les tícs se sont arrêtés après arrêt de la CBZ. Ces cas montrent que la CBZ peut induire des tics moteurs simples chez l'enfant. Ces réactions idiosyncrasiques peuvent être transitoires et na nécessitent pas toujours l'arrêt du médicament.

(P. Genton, Marseille)

\section{RESUMEN}

Aunque se conocen varios trastornos de movimiento durante el tratamiento con carbamazepina (CBZ) en adultos y en niños, el desarrollo de tics ha sido infrecuentemente descrito y sólamente en pacientes que tenían un síndrome de Tourette u otros trastornos del movimiento. Los autores presentan 3 niños con epilepsía que desarrollaron tics motores faciales trans la inicia- ción de un tratamiento con CBZ por padecer crisis parciales complejas. Los 3 enfermos tenían niveles terapéuticos sanguíneos de CBZ y ninguno mostró signos o síntomas de intoxicación. La exploración neurológica fue normal en 2 y el tercero mostró una lentificación en el desarrollo del lenguahe expresivo. Los estudios de imagen cerebral fueon normales en $\operatorname{los} 3$ casos. Tras el desarrollo de los tics, en 2 casos la CBZ se mantuvo en las mismas o en dosis más elevadas y los tics se redujeron. Posteriormente, se interrumpieron espontáneamente en un periodo de 6 meses. En el tercer niño los tics se interrumpieron después de la interrupción de la CBZ. Estos casos demuestran que la CBZ puede inducir tics simples motores en niños. Esta reacción idiosicrásica puede ser transitoria y no se siempre necesita la interrupción de la medicación.

(A. Portera-Sánchez, Madrid) 